\title{
Support Group Therapy untuk Menurunkan Kecemasan Pada Care Giver Odgj di Desa Srigading
}

\author{
Wiwik Lestari, Triantoro Safaria \\ Magister Psikologi Profesi Klinis, Universitas Ahmad Dahlan \\ J1. Kapas No.9, Semaki, Kec. Umbulharjo, Kota Yogyakarta, \\ Daerah Istimewa Yogyakarta 55166 \\ Email: wiwiklestari2770@gmail.com, triantoro.safaria.phd@gmail.com
}

\begin{abstract}
The purpose of this study group was to see the effect of group therapy in reducing cholesterol in ODGJ care givers. There were 6 participants in the group therapy which was a recommendation from the soul cadres of Srigading village. This therapy is carried out in a form analysis using a combination of qualitative and quantitative methods, with a psychodynamic-oriented approach. Group participants are drawn based on the same problem, namely the conclusion. In carrying out the obligations of the ODGJ giver, he is also a direct member of the family who also feels and feels uncomfortable while accompanying ODGJ. The results show that seen from statistical data there is a decrease in the level of attention of the giver after being given group therapy support. The results of the qualitative data also showed a decrease which was known through individual interviews after being given group therapy support.
\end{abstract}

Keywords: Care Giver, Support Group Therapy, Anxiety

\section{Abstrak}

Tujuan penelitian kelompok ini adalah untuk melihat pengaruh support group therapy dalam menurunkan kecemasan pada care giver ODGJ. Peserta dalam terapi kelompok ini sebanyak 6 orang yang merupakan rekomendasi dari kader jiwa desa Srigading. Terapi dilakukan dalam bentuk analisis menggunakan kombinasi metode kualitatif dan kuantitatif, dengan pendekatan yang berorientasi pada Psikodinamika. Peserta kelompok diambil berdasarkan permasalahan yang sama yaitu kecemasan. Dalam menjalankan kewajiban care giver ODGJ sekaligus juga merupakan anggota keluarga secara langsung juga ikut merasakan kekhawatiran dan perasaan tidak nyaman selama mendampingi ODGJ. Hasil menunjukan bahwa dilihat dari data statistik terdapat penurunan tingkat kecemasan care giver setelah diberikan support group therapy. Hasil data kualitatif juga menunjukan adanya penurunan kecemasan yang diketahui melalui wawancara per-individu setelah diberikan support group therapy.

Kata kunci: Care Giver, Support Group Therapy, Kecemasan

\section{Pendahuluan}

Merawat orang dengan gangguan jiwa (ODGJ) terkadang bisa menimbulkan beban dan masalah bagi keluarga atau orang yang merawat salah satunya beban psikologis seperti muncunya perasaan khawatir dan cemas. Yusuf (Annisa \& Ifdil, 2016) berpendapat bahwa anxiety (cemas) diartikan dengan perasaan tidak berdaya terhadap kondisi yang membuat cemas atau merasa tidak aman, tidak matang, dan kurang mampu dalam menghadapi tuntutan lingkungan, kesulitan dan tekanan kehidupan sehari-hari.

Berdasarkan data yang diperoleh dari hasil wawancara individu menunjukan bahwa semua peserta caregiver ODGJ mengalami kecemasan meskipun disebabkan oleh faktor yang berbeda-beda. Caregiver mengalami kecemasan ketika berada pada setting yang berbeda-beda, seperti: di rumah, di sawah, di pasar dan di tempat bekerja. Gejala kecemasan tersebut seperti: berkeringat dingin dan gemetar ketika teringat dengan keluarga yang mengalami gangguan jiwa, takut, jantung berdetak kencang dan tegang ketika melihat perilaku keluarga yang mengalami gangguan jiwa tidak seperti orang pada umumnya. Satu orang caregiver menjadi takut dan berkeringat dingin, jantung berdetak kencang karena merasa malu terhadap tetangga akibat perilaku keluarga yang mengalami gangguan jiwa.

Di samping itu caregiver juga menjelaskan bahwa kecemasan yang dialami akibat dari tekanan psikologis yang dialaminya setelah sekian lama melihat kondisi keluarga yang mengalami gangguan jiwa tidak menunjukan perubahan untuk sembuh. Caregiver mengakui meskipun yang melatarbelakangi keluarganya mengalami gangguan jiwa berbeda-beda, akan tetapi dampak fisik dan psikis yang dialami peserta sama yaitu mengalami kecemasan. Kecemasan juga dialami caregiver ketika anggota keluarga tiba-tiba mengalami gangguan jiwa karena keluarga terlambat 
mengetahui permasalahan keluarga yang bersangkutan, oleh sebab itu caregiver yang juga merupakan anggota keluarga yang mengalami gangguan merasa cemas dan takut terhadap masa depan keluarganya yang mengalami gangguan jiwa.

\section{Metode Penelitian}

\subsection{Pengukuran Pretest}

Berdasarkan hasil pengukuran tingkat depresi, kecemasan dan stres terhadap 6 orang caregiver menggunakan alat ukur DASS, menunjukan bahwa semua peserta memiliki tingkat kecemasan yang berada pada kategori sedang dan tinggi.

Tabel 1. Skor Pretest Peserta Menggunakan DASS

\begin{tabular}{|c|c|c|c|c|}
\hline No & Nama & Depression & Anxiety & Stress \\
\hline 1. & SM & 8 (normal) & 11 (sedang) & 16 (sedang) \\
\hline 2. & BR & 18 (sedang) & 16 (tinggi) & 14 (normal) \\
\hline 3. & MY & 14 (sedang) & 18 (tinggi) & 14 (Normal) \\
\hline 4. & TJ & 19 (sedang) & 16 (tinggi) & 31 (Parah) \\
\hline 5. & MT & 21 (tinggi) & 24 (sangat tinggi) & 23 (sedang) \\
\hline 6. & AM & 22 (Parah) & 14 (sedang) & 31 (parah) \\
\hline
\end{tabular}

Berdasarkan hasil skala pengukuran terdapat 6 peserta yang memiliki permasalahan serupa yaitu mengalami kecemasan pada kategori sedang ke sangat tinggi yang akan mengikuti konseling kelompok.

2.2. Wawancara Per-individu

a) $\mathrm{SM}$

SM mengatakan bahwa merasa cemas melihat keadaan anaknya yang mengalami gangguan jiwa. SM mengakui bahwa anaknya mengalami gangguan semenjak lahir dan ada faktor genetik yang melatarbelakanginya. Pada saat lahir anak SM lahir dengan kondisi kembar, akan tetapi salah satu kembaran anaknya berbeda dengan anaknya yang lain. Sejak anaknya lahir SM merasa khawatir melihat kondisi anaknya tersebut. Meskipun sekarang anaknya sudah berusia 24 tahun, SM masih merasa cemas karena takut terjadi sesuatu terhadap anaknya. SM juga tidak dapat bekerja dengan fokus karena memikirkan anaknya. SM mengakui bahwa sering terbangun di malam hari kemudian menengok anaknya ke dalam kamar untuk memastikan keberadaannya.

b) MY

MY mengungkapkan bahwa mendampingi putranya yang mengalami gangguan jiwa semenjak putranya berada di kelas 1 SD. MY mengatakan bahwa sudah 23 tahun merawat dan mendampingi putranya. Selama mendampingi dan menjaga putranya, MY mengungkapkan bahwa sering merasa khawatir dan merasa cemas melihat kondisi putranya tidak seperti anak pada umumnya.MY mengatakan bahwa anaknya berulang-ulangkali tidak naik kelas 1 SD. MY sering merasa tegang dan merasa tidak tenang memikirkan bagaimana masa depan anaknya. Setiap hari MY merasa was-was dan khawatir karena merasa takut akan terjadi sesuatu yang tidak diinginkan pada anaknya. Di sisi lain MY juga pernah merasa kewalahan mengurus putranya akan tetapi semua itu dipendamnya sendiri dan tetap berusaha memberikan yang terbaik untuk putranya.

c) $\mathrm{AM}$

AM menceritakan bahwa merasa tertekan karena mengurus dan mendampingi suaminya yang mengalami gangguan jiwa. AM mengakui bahwa setiap hari suaminya sering melakukan hal-hal yang tidak disukai olehnya, seperti: merokok di depan anak-anaknya, membawa sandal yang penuh dengan kotoran tanah ke dalam kamar mandi. Meskipun sudah diajari dan dikatakan dengan cara yang baik, suaminya tidak mau mendengarkan. Selain itu BR juga mengungkapkan bahwa asam lambungnya sering naik dan sakit akibat dari pikiran dan perasaannya yang tidak tenang karena perilaku suaminya tersebut. Di sisi lain AM juga mengatakan merasa malu terhadap tetangga karena setiap hari bertengkar dengan suaminya yang melakukan perilaku yang tidak diinginkannya. AM juga mengakui bahwa khawatir dan takut dibicarakan oleh tetangga jika membawa suaminya ke rumah sakit ataupun bertemu dengan psikolog, sehingga AM 
mengatakan banyak memendam perasaan yang tidak bisa diungkapkannya kepada orang lain karena merasa takut dipandang negatif.

d) $\mathrm{MT}$

MT mengatakan bahwa selama mendampingi dan tinggal bersama adiknya yang mengalami gangguan jiwa merasa terkejut dan khawatir terhadap sikap adiknya yang berubah secara mendadak. MT mengakui bahwa perilaku adiknya seperti berbicara sendiri dan sering marah-marah dengan alasan yang tidak jelas mulai semenjak adiknya berusia remaja sekitar 16 tahun. MT merasa cemas karena setiap hari adiknya marah-marah. MT mengatakan bahwa pernah hilang kontrol dan ingin memukul adiknya karena memecahkan barang akan tetapi cepat ditahan oleh kakaknya yang pertama. Di sisi lain MT mengakui bahwa kurang memahami cara mendampingi adiknya yang berskiap seperti itu. MT terkadang merasa pusing dan mual ketika memikirkan jalan keluar atas permasalahan perilaku adiknya tersebut.

e) $\mathrm{TJ}$

TJ menceritakan bahwa anaknya mengalami gangguan jiwa pada saat berusia 15 tahun. Pada saat lahir kondisi anaknya sehat dan tidak mengalami gangguan dari segi aspek apapun. Namun perubahan perilaku anaknya semenjak kejadian gempa bumi tahun 2006 yang bertitik pusat di Kab. Bantul. Setelah kejadian gempa bumi tersebut TJ menyebutkan bahwa perilaku anaknya berubah seperti: sering melamun, menangis, teriak-teriak dan sering dengan tiba-tiba berlari dengan cepat sambil mengatakan "selamatkan aku, selamatkan aku". Namun TJ mengatakan bahwa belum menyadari perilaku anaknya tersebut akan berdampak seperti sekarang. TJ hanya mengira anaknya mengalami ketakutan biasa karena adanya kejadian gempa bumi tersebut. Setelah 1 tahun berlalu perilaku anaknya masih tetap sama sehingga TJ merasa cemas dan khawatir melihat kondisi anaknya tersebut. TJ mencoba dengan sering mengajak anaknya bercerita agar tidakmerasa sendirian. TJ juga mencoba membawa anaknya ke RS untuk berobat. Meskipun sekarang anaknya sudah mulai mampu bercerita dan menjalankan aktivitas sehari-hari, akan tetapi TJ mengatakan bahwa anaknya masih sering berbicara sendiri dengan menutup telinga. Melihat kejadian tersebut TJ merasa khawatir terhadap kondisi anaknya tersebut. TJ selalu memikirkan kondisi anaknya masih bisa disembuhkan atau tidak. TJ mengakui bahwa pola tidurnya terganggu dan sering merasa sakit dibagian perut ketika memikirkan kondisi anaknya tersebut. Di sisi lain TJ mengungkapkan bahwa aktivitasnya juga terhambat karena harus mengurusi keperluan anaknya sebelum melakukan aktivitas lain.

f) $\mathrm{BR}$

BR mengatakan bahwa sudah 5 tahun mendampingi anaknya yang mengalami gangguan jiwa. BR menceritakan bahwa anaknya mengalami perubahan perilaku semenjak SMA karena mengalami bullying dari teman-temannya di sekolah. BR mengatakan menyesali bahwa terlambat mengetahui peristiwa tersebut. Dampak dari kejadian tersebut BR mengatakan bahwa anaknya jadi menarik diri dan tidak mau bergaul dengan orang lain karena merasa tidak percaya diri sehingga anaknya sampai sekarang lebih banyak menghabiskan waktu di dalam rumah dibandingkan bertemu dengan orang lain di luar rumah. Melihat kondisi anaknya tersebut BR mengatakan bahwa merasa kurang tidur dan sering terlambat makan sehingga asam lambungnya sering naik dan mengakibatkannya mual-mual. Kondisi tersebut diakui BR dialaminya ketika terlalu memikirkan masa depan anaknya. Di sisi lain meskipun BR selalu rutin membawa anaknya berobat ke RS, namun BR tidak dapat memungkiri bahwa sering merasa cemas dan mengalami perasaan tegang ketika memikirkan anaknya.

\subsection{FGD}

Berdasarkan FGD yang dilakukan didapatkan hasil bahwa 2 orang peserta yaitu BR dan TJ merasa was-was dan khawatir yang menyebabkan asam lambungnya naik meskipun anaknya yang mengalami gangguan jiwa telah dibawa berobat ke RS. BR dan TJ merasa khawatir terhadap masa depan anaknya. Selain itu BR dan TJ juga mengakui bahwa pola tidurnya terganggu sehingga menyebabkan aktivitasnya sehari-hari tidak berjalan dengan lancar. Sedangkan SM juga mengakui bahwa aktivitasnya terhambat dan juga tertekan selama mendampingi anaknya yang mengalami gangguan jiwa, hal ini dikarenakan anaknya sering pergi keluar rumah dan sering tidak tau jalan pulang sehingga SM harus mencari anaknya. Oleh sebab itu SM mengatakan 
aktivitasnya jadi terhambat karena pekerjaannya sebagai pedagang di pasar yang mengharuskannya untuk cepat datang dan mencari tempat untuk berjualan di pasar. Namun karena anaknya sering pergi keluar rumah SM sering terlambat berangkat ke pasar. Selain itu SM mengatakan bahwa sebenarnya anaknya terlahir kembar namun satu anaknya mengalami gangguan jiwa tetapi kembarannya yang lain normal, sehingga kondisi ini juga menjadi penyebab SM sering merasa cemas dan khawatir memikirkan perasaan anaknya yang mengalami gangguan jiwa. SM merasa takut anaknya yang gangguan jiwa merasa minder dan tidak percaya diri ketika melihat saudara kembarannya normal seperti anak yang lain. Kondisi ekonomi yang relatif rendah menjadi salah satu faktor SM tidak membawa anaknya ke Rumah Sakit, sehingga hal tersebut membuat SM sering merasa cemas dan khawatir memikirkan nasib keluarganya. SM juga mengatakan sering sakit dipunggung bagian belakang, kepala pusing ketika ditengah malam tidak bisa tidur memikirkan kondisi keluarganya.

Selanjutnya peserta MT mengatakan bahwa merasa gelisah dan takut ketika melihat perubahan perilaku adiknya secara tiba-tiba menyebabkannya merasa tidak tenang dan tertekan ketika berada di rumah. MT menyebutkan bahwa muncul keinginan untuk marah kepada adiknya ketika melempar barang di rumah, namun keinginan untuk marah masih ditahannya sehingga kerap menimbulkan tegang dan gemetar yang dialami MT. Di sisi lain pada waktu malam hari MT mengakui bahwa jantungnya berdetak kencang ketika memikirkan kondisi adiknya sehingga menyebabkan ia sulit untuk tidur dengan tenang. Di samping itu MT mengatakan perasaan khawatir yang dirasakan dipendamnya sendiri hal ini dikarenakan MT tidak ingin membuat anggota keluarga lain menjadi ikut khawatir jika ia menceritakan prasaannya. Namun MT ketika merasa tidak tenang mencoba mencari tempat untuk dapat menyendiri untuk menghilangkan kecemasannya seperti: pergi memancing ikan.

Selanjutnya peserta AM juga merasa tertekan selama mendampingi dan merawat suaminya yang mengalami gangguan jiwa. AM menceritakan bahwa sering merasa tegang dan kesal terhadap suaminya yang setiap hari melakukan hal-hal yang tidak diinginkannya. Meskipun AM sudah mencoba untuk menjelaskan kepada suami dengan cara baik-baik akan tetapi suami tidak mendengarkan. Selain itu AM juga merasa malu terhadap tetangga karena perilaku suaminya yang sering marah-marah dan berteriak. Namun di sisi lain AM mengakui bahwa tidak memiliki pengetahuan dan pemahaman terkait gangguan jiwa sehingga AM merasa binggung dalam melakukan sesuatu. AM juga menyebutkan bahwa tidak membawa suaminya ke RSJ dikarenakan penghasilannya yang rendah sehingga tidak cukup untuk membawa suaminya untuk berobat ke RSJ.

Sedangkan peserta MY sering merasa tegang dan merasa tidak tenang memikirkan bagaimana masa depan anaknya. Setiap hari MY merasa was-was dan khawatir karena merasa takut akan terjadi sesuatu yang tidak diinginkan pada anaknya. Di sisi lain MY juga pernah merasa kewalahan mengurus putranya akan tetapi semua itu dipendamnya sendiri dan tetap berusaha memberikan yang terbaik untuk putranya. Berdasarkan FGD yang dilakukan, maka dapat disimpulkan bahwa semua peserta mengalami kecemasan yang disebabkan oleh masalah terkait pendampingan dan merawat keluarga yang mengalami gangguan jiwa.

\subsection{Hasil Asesmen}

Berdasarkan asesmen yang dilakukan didapatkan seluruh peserta memiliki permasalahan dengan emosinya terutama mengalami kecemasan. Permasalahan yang dialami peserta seperti : merasa khawatir, takut dan cemas terhadap situasi kehidupan yang menegangkan baik terhadap yang sedang terjadi maupun belum terjadi seperti ketakutan tentang nasib buruk dimasa depan yang akan terjadi pada keluarganya. Rasa cemas yang dialami memberi respon fisiologis dan juga psikis. Respon yang ditunjukkan seperti: Jantung berdebar lebih kencang, lemas, kepala terasa pusing, tangan yang gemetar, mual dan keringat dingin, sakit pada bagian tubuh seperti sakit pinggang. Sedangkan respon psikis seperti mudah marah dan tersinggung, menjadi sensitif dengan orang lain, sulit untuk konsentrasi, merasa gelisah, tidak dapat santai/rileks, pola tidur terganggu dan merasa lelah. Meskipun masing-masing peserta memiliki upaya untuk mengurangi kecemasan, akan tetapi cara tersebut dirasa kurang efektif. Peserta justru merasa jika upaya tersebut menyebabkan kecemasan yang dirasa semakin meningkat. 


\subsection{Tipe Pendekatan dan Therapy}

Tipe pendekatan kelompok yang adalah pendekatan yang berorientasi pada terapi psikodinamika yaitu terapi supporyive group. Terapi supportif merupakan suatu bagian dari psikoterapi yang bisa digunakan pada komunitas dibidang psikiatrik. Berbeda dari tipe yang lain terapi suportif adalah salah satu terapi yang berorientasi atau mengarah pada pendekatan psikodinamika namun bersifat campuran dengan menggabungkan terapi dari pendekatan lain. Supportive group atau kelompok suportif adalah salah satu teknik intervensi dengan setting kelompok atau lebih dari satu orang dengan ciri-ciri memiliki permasalahan yang sama untuk saling mendukung, mengondisikan dan memberi penguatan pada kelompok, maupun per-individu dalam suatu kelompok.

Tujuan utama dari terapi kelompok suportif yaitu tercapainya kemampuan coping yang lebih efektif terhadap masalah yang sedang dialami. Dengan demikian kelompok yang memiliki permasalahan yang sama dan memiki permasalahan yang sama dapat memberikan kesempatan bagi individu dalam kelompok untuk saling belajar serta saling memberikan semangat satu sama lain (Corey, 2010). Terapi kelompok suportif setiap anggota kelompok dapat saling berbagi informasi dan pengalaman, serta memiliki kesempatan yang sama untuk menyampaikan keluh kesah yang telah atau sedang dihadapi sebagai bentuk katarsis atau sebagai wadah untuk mengungkapkan emosi dan perasaan-perasaan yang terpendam selama ini (Brabender, Fallon, \& Smollar, 2004).

Penelitian terdahulu terdapat terapi suportif sangat efektif dalam mengatasi dan mengurangi perasaan cemas yang dialami seseorang (Lipsitz et al, 2008). Pada remaja di rumah tahanan yang mengalami kecemasan, terapi suportif bisa berguna dalam menjelaskan kepada remaja tentang mengenal sumber coping dan menggunakan sumber coping yang telah diidentifikasi untuk mengatasi kecemasan yang dialami sehingga kecemasan dapat dicegah atau dikurangi. Dengan demikian, dengan memberikan terapi suportif anggota kelompok mampu menemukan cara memecahkan masalah yang tepat dalam menghadapi permasalahan bullying, meningkatkan motivasi dan kepercayaan diri peserta sehingga kecemasannya dapat menurun.

\section{Hasil dan Pembahasan}

\subsection{Hasil Postest}

Tabel 2. Hasil Pretest dan Postest

\begin{tabular}{|l|c|c|c|c|c|}
\hline No & Nama & Skor pretest & Kategori & Skor posttest & Kategori \\
\hline 1 & SM & 11 & Sedang & 6 & Rendah \\
\hline 2 & BR & 16 & Tinggi & 6 & Rendah \\
\hline 3 & MY & 18 & Tinggi & 5 & Rendah \\
\hline 4 & TJ & 16 & Tinggi & 6 & Rendah \\
\hline 5 & MT & 24 & sangat tinggi & 6 & Rendah \\
\hline 6 & AM & 14 & Sedang & 5 & Rendah \\
\hline
\end{tabular}

a. Hasil analisis dengan uji statistic non parametric Wilcoxon

\section{Descriptive Statistics}

\begin{tabular}{|l|r|r|r|r|r|}
\hline & $\mathrm{N}$ & \multicolumn{1}{|c|}{ Mean } & Std. Deviation & \multicolumn{1}{|c|}{ Minimum } & \multicolumn{1}{c|}{ Maximum } \\
\hline pretest & 6 & 16,50 & 4,370 & 11 & 24 \\
postest & 6 & 5,67 &, 516 & 5 & 6 \\
\hline
\end{tabular}




\begin{tabular}{|c|c|}
\hline \multicolumn{2}{|c|}{ Test Statistics $^{\mathrm{a}}$} \\
\hline & postest - pretest \\
\hline $\begin{array}{l}\text { Z } \\
\text { Asymp. Sig. (2-tailed) }\end{array}$ & $\begin{array}{r}-2,207^{\mathrm{b}} \\
, 027\end{array}$ \\
\hline
\end{tabular}

a. Wilcoxon Signed Ranks Test

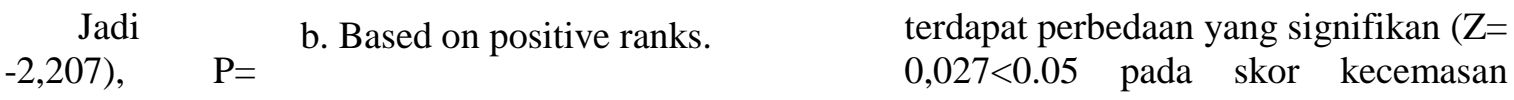
sebelum diberikan terapi $(\mathrm{M}=16,50, \mathrm{SD}=4,370)$ dengan skor kecemasan setelah diberikan terapi $(\mathrm{M}=5,67, \mathrm{SD}=5,16)$.

b. Grafik Skor Pretest dan Postest

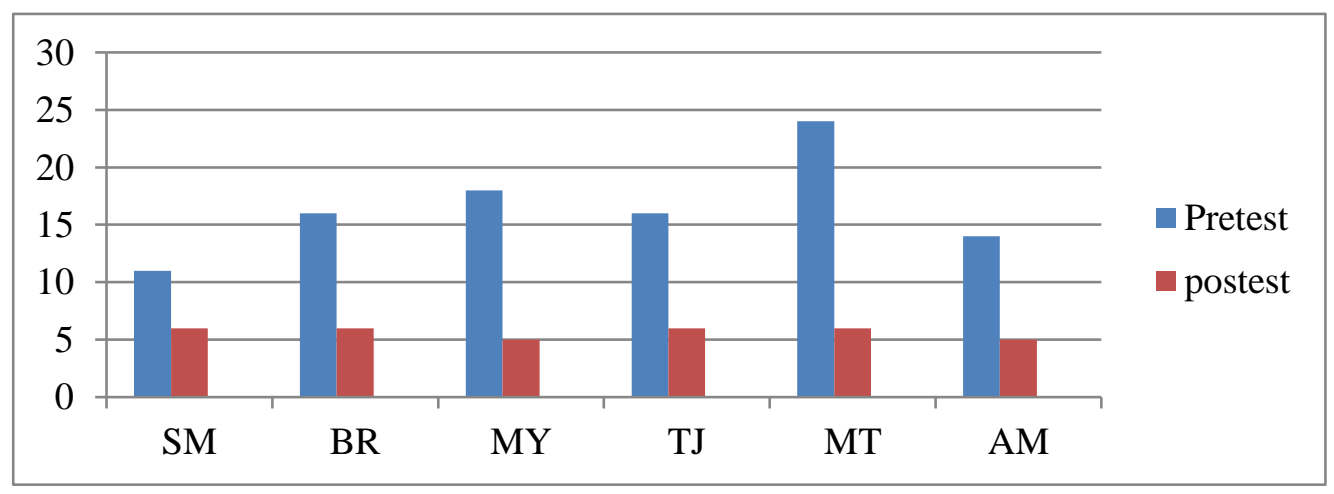

Berdasarkan hasil skor pretest dan posttest dapat dilihat bahwa terjadi penurunan tingkat kecemasan yang dialami oleh keenam peserta. Hasil pretest menunjukkan bahwa 2 peserta mengalami kecemasan dalam kategori sedang, dan 3 orang mengalami kecemasan dalam kategori tinggi dan 1 orang mengalami kecemasan sangat tinggi. Sedangkan pada hasil postest menunjukkan bahwa 6 orang peserta mengalami kecemasan dalam kategori rendah.

\subsection{Pembahasan}

Hasil terapi kelompok menunjukkan adanya perubahan pada tingkat kecemasan yang dialami peserta antara sebelum dan sesudah mengikuti proses terapi kelompok dengan nilai signifikansi $\mathrm{P}=0,027<0.05$, hasil intervensi yang menunjukkan berkurangnya tingkat kecemasan setelah peserta diberikan terapi supportif sesuai dengan penjelasan dari penelitian terlebih dahulu yang telah dilakukan oleh Shechtman dan Katz (2007) membuktikan bahwa terapi kelompok suportif cukup efektif untuk menurunkan tingkat kecemasan sekelompok remaja yang mengalami gangguan belajar dalam membangun hubungan sosial dan persahabatan dengan orang lain. Responden dari penelitian tersebut menyatakan manfaat dari pemberian terapi karena memperoleh kesempatan mengungkapkan perasaan dan berbagi pengalaman yang tidak menyenangkan dengan responden lainnya dalam satu kelompok.

Sedangkan menurut penelitian Nurcahyani, dkk (2016) membuktikan bahwa terapi suportif sangat efektif diberikan pada kelompok korban bencana dalam menurunkan kecemasan. Dalam penelitian ini pemberian terapi supportif sangat berpengaruh dalam menurunkan kecemasan pada kelompok yang mengalami bencana banjir bandang. Hal ini disebabkan karena subjek penelitian merasa tidak sendirian dan menyadari bahwa masih ada orang lain yang juga merasakan hal yang sama dengannya.

Supportive group atau kelompok suportif adalah suatu kelompok yang memiliki permasalahan yang sama untuk saling mendukung, mengondisikan dan memberi penguatan pada kelompok, maupun per-individu dalam kelompok. Tujuan utama dari terapi kelompok suportif adalah tercapainya kemampuan koping yang efektif terhadap masalah yang dialami. Adanya kelompok yang memiliki permasalahan yang sama memiki permasalahan yang sama dapat 
memberikan kesempatan bagi individu dalam kelompok untuk saling belajar dan menguatkan satu sama lain (Corey, 2010). Terapi kelompok suportif memfasilitasi setiap anggota kelompok untuk dapat saling berbagi informasi dan pengalaman, serta memiliki kesempatan yang sama untuk menyampaikan keluh kesah yang telah atau sedang dihadapi sebagai bentuk katarsis (Brabender, Fallon, \& Smollar, 2004).

Dalam kasus ini, seluruh peserta menyatakan kurang percaya diri, cemas dan khawatir yang berlebihan dan menganggap dirinya lebih rendah karena memiliki anggota keluarga yang mengalami gangguan jiwa sehingga berdampak pada hubungan sosial, yakni adanya perasaan minder, takut di tolak, penghindaran dan terbatasnya lingkup pertemanan. Penilaian terhadap diri disebut juga sebagai konsep diri. Konsep diri (self concept) adalah evaluasi individu mengenai diri sendiri; penilaian atau penaksiran mengenai diri sendiri oleh individu yang bersangkutan (Chaplin, 1995). Evaluasi, penilaian, atau penaksiran berarti individu menggambarkan dirinya dan memberikan nilai mengenai dirinya sendiri. Secara umum penilaian tentang konsep diri dibagi menjadi dua bagian, yaitu konsep diri positif dan konsep diri negatif. Salah satu ciri individu yang memiliki konsep diri positif adalah mampu menerima dan mencintai diri sendiri apa adanya, sedangkan salah satu ciri individu yang memiliki konsep diri negatif adalah tidak mampu menerima dan mencintai diri sendiri apa adanya (Rakhmat, 2005). Rasa percaya diri seseorang sangat erat berkaitan dengan konsep diri seseorang (Rakhmat, 2005).

Pengetahuan tentang diri akan meningkatkan kemampuan interaksi sosial, dan pada saat yang sama, berinteraksi dengan orang lain meningkatkan pengetahuan tentang diri kita. Dengan membuka diri, konsep diri menjadi lebih dekat pada kenyataan. Bila konsep diri sesuai dengan pengalaman kita, kita akan lebih terbuka untuk menerima pengalaman-pengalaman dan gagasangagasan baru, lebih cenderung menghindari sikap defensif, dan lebih cermat memandang diri kita dan orang lain. Makin luas diri publik kita, makin terbuka kita pada orang lain, dan makin akrab hubungan kita dengan orang lain (Rakhmat, 2005).

Perlakuan yang tidak menyenangkan yang dialami peserta menimbulkan kecemasan. Kecemasan yang dialami menyebabkan jantung berdebar dan tubuh berkeringat. Beberapa peserta mengeluhkan adanya ketakutan dan penghindaran terhadap orang-orang tertentu, ketakutan tersebut menimbulkan perasaan gugup dan perasaan khawatir saat ingin melakukan sesuatu. Individu yang cemas secara sosial cenderung untuk menarik diri dan tidak efektif dalam interaksi sosial, ini dimungkinkan karena individu tersebut mempersepsi akan adanya reaksi negatif. Kecemasan yang terjadi pada diri individu akan membuat individu tersebut merasa rendah diri, meremehkan diri sendiri, menganggap dirinya tidak menarik dan menganggap dirinya tidak menyenangkan untuk orang lain.

Individu yang mengalami kecemasan ditandai dengan ketegangan otot dan adanya tingkat kewaspadaan yang sangat tinggi. Kemudian, individu tersebut akan menolak untuk bersosialisasi dengan orang lain supaya ketegangannya berkurang (Teichman, 1974, dalam Dewi, 2006).

Terdapat penelitian-penelitian sebelumnya yang mendukung keefektifan pemberian terapi kelompok suportif untuk menurunkan kecemasan. Puspitasari, 2016 meneliti efektivitas terapi kelompok supportif yang berpengaruh untuk menurunkan kecemasan pada remaja yang mengalami kehamilan di luar nikah. Penelitian Dewi, 2011 membuktikan bahwa terapi kelompok supportif berpengaruh pada beban dan tingkat ansietas keluarga dalam merawat anak tunagrahita di sekolah luar biasa Kabupaten Banyumas. Dalam hal ini terapi suportif dapat digunakan sebagai cara menurunkan kecemasan pada siswa akibat bullying. Terapi ini dilakukan agar peserta mampu mengatasi kecemasannya dalam menghadapi situasi yang tidak menyenangkan.

Hasil penelitian yang telah dijelaskan sebelumnya menunjukkan kesesuaian dengan hasil yang diperolah oleh para peserta yang mengikuti intervensi kelompok. Peserta yang mendapatkan terapi suportif mengalami penurunan tingkat kecemasan dari sebelum mengikuti terapi. Setelah diberikan terapi, peserta menjadi lebih aktif, percaya diri dan mampu mengelola dirinya ketika menghadapi situasi yang tidak menyenangkan. Terapi suportif kelompok juga membuat peserta lebih mengenal dirinya, menyadari perasaannya dan lebih terbuka kepada orang lain sehingga dapat menjadi sarana bagi peserta untuk saling memberikan dan mendapatkan dukungan dari orang sekitar. 
Terapi kelompok yang diberikan yaitu dengan teknik yaang berfokus pada Praise \& Encouragment. Teknik ini meminta peserta untuk terlibat aktif dalam mendengarkan secara empatik ketika peserta lain sedang bercerita dan mengarahkan tanggapannya kepada pengehargaan positif atas usaha dan pencapaian yang telah dilakukan peserta dalam menghadapi permasalahannya serta memberikan motivasi secara emosi agar peserta lain dapat merasakan dorongan dari anggota kelompok. Kondisi ini membuat terapis mengajak peserta untuk lebih menggunakkan pada bahasa verbal dan ungkapan secara langsung dengan bermodalkan kedekatan serta empati yang telah nampak pada setiap peserta. Hal ini dilakukan agar peserta menyadari bahwa tidak sendiri dan masih ada orang lain yang juga merasakan hal serupa dengannya. teknik ini diberikan kepada semua peserta yang memiliki tingkat kecemasan dari kategori sedang sampai tinggi yang diperoleh dari asesmen berdasarkan skala DASS pada pre-test. Selanjutnya setelah diberikan terapi maka dilakukan post-test dengan mengisi skala DASS, hal ini dilakukan untuk melihat perbandingannya sebelum dan sesudah diberikannya Supportive Group. Berdasarkan pemberian Supportive Group pada care giver yang mendampingi ODGJ memperoleh hasil yang sangat efektif, hal ini terlihat dari skor skala post-test DASS yang diisi oleh ke-6 peserta.

\section{Kesimpulan}

Berdasarkan proses asesmen dan terapi yang diberikan kepada care giver diperoleh hasil bahwa support group therapy dapat menurunkan kecemasan pada care giver ODGJ

\section{Daftar Rujukan}

[1] Azwar, Reliabilitas Dan Validitas. Yogyakarta: Pustaka Pelajar. 2012.

[2] Brabender, V.A., Fallon, A.E., \& Smolar, A.I, Essential Of Group Therapy. New Jersey: John Wiley \& Sons, Inc. 2004

[3] Chaplin, J.P, Kamus Lengkap Psikologi. Jakarta: PT. Raja Grafindo. 1995.

[4] Corey, G, Theory And Practice Of Group Counselling (8th Edition). Belmont, CA, USA: Brooks/Cole, Cengage Learning. 2010.

[5] Dewi, A. P, "Hubungan Antara Pola Pikir dengan Kecemasan Berbicara di Depan Umum Pada Mahasiswa Fakultas Keguruan”, Skripsi (Tidak Diterbitkan). 2006.

[6] Dewi, E. I, "Pengaruh Terapi Kelompok Suportif Terhadap Beban dan Tingkat Ansietas Keluarga Dalam Merawat Anak Tunagrahita di Sekolah Luar Biasa (SLB) Kabupaten Banyumas". Naskah Publikasi. Universitas Indonesia. 2011.

[7] Hidayah. K, "Hubungan Konsep Diri dengan Kecemasan Sosial Pada Siswa Kelas 2 SMAN 1 Tumpang", Naskah Publikasi. Universitas Islam Negeri (UIN) Maulana Malik Ibrahim. Malang. 2017

[8] La Greca, A. M, Lopez, N, "Sosial Anxiety Among Adolescent: Linkages With Peer Relation And Friendship", Journal Of Abnormal Child Psychology. Vol.26(2): 83-94. 1998.

[9] Lipsitz, Et. Al, A Randomized Trial Of Interpersonal Therapy Versus Supportif Therapy. For Social Anxiety Disorder. Www. Interscience.Wiley.Com. Diperoleh Tanggal 3 Agustus 2019.

[10] Nurcahyani, dkk, "Pengaruh terapi suportif kelompok terhadap kecemasan pada klien pasca bencana banjir bandang di perumahan relokasi Desa Suci Kecamatan Panti Kabupaten Jember". E-Jurnal Pustaka Kesehatan. Vol 4 (2): 293-299. 2016.

[11] Olivares, "Social Anxiety Scale For Adolescent (SAS-A) : Psychometric Properties In A Spanish-Speaking Population", International Journal Of Clinical And Health Psychology. 2005.

[12] Puspitasari, R. A, "Efektivitas Terapi Kelompok Suportif Untuk Menurunkan Kecemasan Pada Remaja yang Mengalami Kehamilan di Luar Nikah. Naskah Publikasi. Universitas Indonesia. 2016.

[13] Rahmat, J, Psikologi Komunikasi. Bandung: Remaja Rosdakara. 2005.

[14] Rockland, L. H, "A Review Of Supportive Psychotherapy 1986-1992", Journal Of Hospital And Community Psychiatry. 44(11) : 1053-1060. 1993.

[15] Scechtman Dan Katz, "Therapiutic Bonding In Group As An Explanatory Variable Of Progress In The Social Competence Of Students With Learning Disabilities University Of Haifa, Israel", Group Dynamic : Theory, Research, And Practice. American Psychological Association, Vol.11, No.2 : 117-128. 2017.

[16] Sejiwa, Bullying : Mengatasi Kekerasan Di Sekolah Dan Lingkungan Sekitar Anak. Jakarta : PT Grasindo. 2008.

[17] Sripurwaningsih. I. M, "Hubungan Perundungan (Bullying) Dengan Kepercayaan Diri Siswa Kelas X Sma Muhammadiyah 1 Karanganyar Tahun Ajaran 2016/2017", Naskah Publikasi. Institut Agama Islam Negeri Surakarta. 2017. 
Wiwik Lestari, Triantoro Safaria

Psyche 165 Journal Vol 14 No 2 (2021) 139 - 147

[18] Viederman, "A Model For Interpretative Supportive Dynamic Psychotherapy”, Journal Of Psychiatry. 71(24). New York. 2008

[19] Wiyani, Ardy, Save Our Children From School Bullying. Jogjakarta : Arruzz Media. 2012. 